The International Journal of Banking and Finance, Volume 9 (Number 2) 2012: pages 1-25

\title{
BANK MERGERS AND COMPETITION IN JAPAN
}

\author{
Kang H. Park \\ Southeast Missouri State University, United States of America
}

\begin{abstract}
Using H-statistic of the Panzar-Rosse model, this paper examines commercial bank merger waves in Japan and their effect on competition in the Japanese banking market during 1983-2006. The H-statistic is estimated separately for three different time periods, the boom, the burst and the recovery. This paper concludes that the bank mergers that took place in Japan have not led to a higher level of market power except during the period of financial crisis around the time of bubble burst. Recent mergers in the Japan's banking sector do not seem to harm the competition level in the banking market. An increase in individual bank's market share and an increase in overall market concentration have not materialized in higher net interest margin in Japan.
\end{abstract}

Key Words: Bank consolidation, Market competition, Japanese banks, Bubbles, Korea, Japan, China

JEL Classification: G21, L10

\section{Introduction}

The Japanese and South Korean banking industries share commonality in their merger activities and market concentration trends. That is, in Japan there is an increase in bank mergers, resulting in the creation of mega banks resulting in an increase in the overall market concentration. Even with a decrease in market concentration, the Chinese banking industry too is still highly concentrated and its level of competition is close to one nearing oligopoly although there have been little movements in banking concentration. However, both the Japanese and South Korean banking industries have a market structure of monopolistic competition, which is more desirable than that of banks in China with oligopolistic trend. The city banks in Japan tend to be more competitive than their South 
Korean counterparts while the South Korean regional banks are more competitive than their Japanese counterparts. Given these overall understanding, it is time to examine the efficiency changes in Japan over a longer period to see what has occurred intertemporally, hence this study.

There has been a surge of mergers and acquisitions of business firms over the last twenty years in the world, so too in Japan. ${ }^{1}$ Although mergers and acquisitions have occurred for a long time, consolidation of firms occurred in the past two decades at a faster phase, in the so-called fifth merger wave, which has been the most remarkable. In a similar way, mergers and acquisitions in the banking industry have been accelerating across countries over the last two decades. The banking industries all over the world have experienced a fundamental change in its market structure via rapid consolidation in the face of both de-regulations and technology infusion. Domestic financial deregulation and financial globalization triggered fierce competition among banks within and across countries. These necessitated consolidation of banks to reduce risk through business diversification and also to take advantage of scale economies therefrom.

The waves of mergers in the banking industry raise important questions of public policy as to whether mergers improve bank efficiency, enhance profitability or lessen market competition. Many studies have tried to address these questions by examining performance of merged banks. However, most of these empirical studies analyzed bank efficiency, profitability or competition in the United States (US) or Europe. The purpose of this paper is to study the effect of bank mergers on the degree of market competition in the Japanese banking industry to address its efficiency: we apply a current methodology.

This paper is organized in the following manner. Section 2 describes Japan's banking system while section 3 discusses the financial crisis that occurred during the late 1990s in Japan. A description of the bank merger waves in Japan following that financial crisis is attempted in section 4 . Section 5 is a brief detour on the merger experiences of China, South Korea and the US to provide a common base. Section 6 briefly surveys the related literature on bank mergers and market competition in the banking sector. The

\footnotetext{
${ }^{1}$ The US banking industry has responded to the pointed reforms in the1980s and in the 1990s by engaging in large scale mergers that led to the 15,000 or so banks being reduced to less than 8,000 in the 2010 s.
} 
reader will find in section 7 the model used to test the degree of competition. The main results on Japan are presented in section 8 along with description of the data and the variables used in this study as well as interpretation of the estimated results on Japan. In section 9, the Korean and Chinese experiences are documented. The paper ends with conclusions in section 10 .

\section{Banking System in Japan}

The banking system in Japan consists of various bank types such as city banks, trust banks, two-tier regional banks, Shinkin banks (shinyou kinko) and credit cooperatives (shinyou kumiai). Among them, city banks are by far the largest and most influential banks, providing comprehensive banking services including both traditional and nontraditional services to large corporate customers. These banks are nationwide banks with a wide geographical scope. Most of these banks act as main banks that maintain shareholdings in Keiretsu firms of the main customers and vice versa: this is a unique feature of main banks.

There were twenty city banks in the 1980s, grown through bank failures and mergers, which decreased to thirteen by the 1990s: by 2007 there were just six city banks. Trust banks in Japan are authorized to do both banking and trust activities. Traditionally they provide funds to corporations and receive deposits from trusts. In recent years their business focus shifted to asset management. Under the Financial System Reform Law of 1992, the number of trust banks almost doubled. These too went through mergers and acquisitions resulting in its number being reduced to twenty in 2007 (Liu, 2009).

The first tier regional banks (chiho ginko) are chartered under the Banking Act, operating within each prefecture. This is akin to US state chartering of banks. There were 64 of these banks in 2007. Their customer bases are local, small and medium size

businesses, households and local governments. Almost three-fourths of their deposits are time deposits and these banks are the main source of small and medium business loans. The second tier regional banks (sogo ginko) were established initially as mutual banks and then transformed into regional banks under the Banking Act of 1992. A total of 45 
banks were in operation in 2007. Although their size is somewhat smaller than the first tier regional banks, their services are similar, serving the needs of small businesses, households and local governments.

Shinkin banks known as credit cooperatives, with 280 banks in 2007, are different from other banks mentioned above in several aspects. First, they are chartered under the Shinkin Bank Act, a different legislation from the Banking Act. Second, they are nonprofit financial institutions with membership requirements like credit unions in the US and other countries. Members take part in ownership and profit-sharing to some limited extent. These banks are also allowed to accept deposits from non-member customers. Third, they are small in scale compared to ordinary commercial banks, and focus on financing small business customers within their local areas.

Credit cooperatives (shinyou kumiai) numbering 164 in 2007 are basically similar to Shinkin banks in their banking services provided and the customer bases served. The only difference is that these cooperatives are supervised by the prefecture government while Shinkin banks are under the supervision of the central government or the Ministry of Finance. Therefore, their operation is limited to their respective prefectures geographically (Uchida and Udell, 2009). Scale difference among the various types of banks can be seen from the different amounts of average outstanding domestic loans in 2000; 2,379 billion yen for city banks, 212 billion yen for tier 1 regional banks, 95 billion yen for tier 2 regional banks, and 18 billion yen for Shinkin banks.

In addition to the above ordinary banks, there are several special banks such as long-term credit banks and financial institutions for small businesses, agriculture, forestry and fishery. Long-term credit banks provide long-term working capital to corporations in the form of loans and guarantees, and contribute to economic growth of the Japanese economy by involving in financing shipbuilding, steel and petro-chemical industries in the past. However, as demand for long-term credit by manufacturers diminishes, these banks are at the verge of extinction with only one bank remaining. In recent years, new types of banks such as settlement banks and internet banks cropped up in the Japanese banking system. 


\section{Financial Crisis in Japan}

The Japanese economy was at its peak performance till the late 1980s and Japanese banks by size were then counted to be among the top 10 largest banks in the world. However, the very size precipitated the financial crisis, and led to their slow demise over later time period.

The easy monetary policy was carried out by the Bank of Japan in the 1980s. The result was low cost credit that caused excess demand in various sectors of the economy, for example as real estate overinvestment, industrial overcapacity and the stock market boom. At the end of the 1980s, the Japanese economy became a bubble economy, with land prices and the stock price index doubling in a short time period. These phenomena were propelled by excessive bank lending in real estate and construction. When the Bank of Japan responded with credit tightening in the early 1990s to control the over-heated economic activities, the asset bubble started to burst leading to asset deflation, also the subsequent collapse of the real estate market as well as the stock market. The land prices dropped by 20 per cent in 1992: by 1997 real estate lost about 60 per cent value.

With the collapse of the bubble economy, many banks ended up with an excessive level of non-performing loans. The Ministry of Finance estimated non-performing loans of twelve per cent of total loans and credits in 1997. While the collapse of real estate market triggered the financial crisis, bankruptcy of many large banks and financial institutions burdened with high rates of non-performing loans contributed greatly to a magnifying effect of the financial crisis in the late 1990s. A banking crisis occurred in 1997, when three large financial institutions, including a city bank named Hokkaido Takushoku Bank, failed. In the subsequent year, two long-term credit banks named the Long-term Credit Bank of Japan and the Nippon Credit Bank failed (Hosono, et al. 2007). The Japanese government let Hokkaido Takushoku Bank, Sanyo Securities and Yamaichi Securities go bankrupt while other banks such as the Long-term Credit Bank of Japan and the Nippon Credit Bank were bailed out.

During the 1990s, Japanese banks in the midst of a deflationary macroeconomic environment, suffered from very low interest margin charged on loans coupled with high 
default rates of outstanding loans from previous era. To make things worse, they made big losses from their investments in Southeast Asia, in Korea, Indonesia and Thailand, as precipitated by the Asian financial crisis of 1997-1998.

The immediate response by the Japanese government was to inject capital as bailout by providing additional funds for deposit insurance. Then a series of financial deregulation and financial system reforms were designed and implemented following the financial crisis. For example, strict accounting standards in implementing the Basel capital standards were applied and bank recapitalization was required, which prompted bank restructuring, which is the stimulus for the mergers that followed. In 1998, Financial Supervision Agency (FSA) was set up to take over bank supervisory function which was previously done by the Ministry of Finance. The world was at that time moving away from putting prudential oversight in the central banks, and this was a knee-jerk response to increase attention to the already badly-off banks.

\section{Bank Merger Waves in Japan}

The banking system in Japan went through fundamental changes after the financial crisis, beginning in the mid 1990s (Casu, et al., 2006). Financial deregulation permitted financial institutional diversification of their business and also deregulation of bond markets, which forced commercial banks to seek new ways of raising funds and utilizing their assets. This change resulted in an increase in loans to small and medium size banks by large commercial banks, which shunned away from such lending in the past. However, the most significant change in the banking system after financial deregulation was a surge of mergers and acquisitions of banks.

Banks mergers occurred very rarely in Japan since the World War II before the 1990s. The numbers of city banks, regional banks and Shinkin banks remained stable until 1990. Only few cases of mergers at different levels of commercial banks, that is, at city bank level, regional bank level and Shinkin bank level, were reported. A small number of mergers before the financial crisis can be explained by the government policy of convoy system. The Ministry of Finance and other governmental regulatory 
authorities, with the intention to stabilize the banking sector, restricted competition among banks, even restricting opening new branches and preventing banks from doing security transactions.

Furthermore, when some banks were at the risk of bankruptcy, the government asked financially sound banks to rescue financially distressed banks with injection of capital and management help. In some cases, the government directly bailed out the troubled banks with government funding. Financially sound banks usually accepted government request for two reasons. First, they do not want to have negative repercussions from the powerful regulatory authorities by refusing to comply. Second, they could extend their branch network by obtaining branches of failing banks. So, most of mergers and acquisitions occurred before the financial system reforms were in place by government as request for sound banks to take over failed banks.

Financial liberalization and financial deregulation which started in the 1980s and continued in the 1990s made this kind of convoy system not workable. In particular, when the risk-based capital requirements on the basis of the Basel standard were implemented in 1992, financially weak banks sought for survival through consolidation. Two mergers among city banks and three mergers among regional banks occurred in the first half of the 1990s. Mergers among Shinkan banks also occurred more frequently in the 1990s than before (Hosono, et al. 2007).

In 2002, FSA announced Financial Rehabilitation Plan, which required financial institutions apply strict accounting standards and reduce their non-performing loans to one-half of the then exiting level. The plan kicked in big merger waves of banks in the early 2000s because financially unsound banks had to be consolidated in order to survive. Through several mergers among major city banks during the early 2000s, mega banks were established under three financial holding companies. They are Mizuho Financial Holdings, Mitsui-Sumitomo Banking Corporation, Mitsubishi-Tokyo-UFJ Financial Holdings. Many mergers among regional banks and among Shinkin banks also occurred in the early 2000s with encouragement and financial support from the government. However, no mega banks were created from the regional or Shinkin bank groups, and their numbers are still in excess of 100. During these merger waves, FSA refrained from 
intervening in mergers by maintaining hands off policy away from the previous practice of rescuing financially distressed banks or arranging or mergers among banks.

As a result of the merger waves, the market share of total bank deposits held by the top three banks increased from the 25 per cent level in 1990 to 40 per cent level in 2006. (However, this level is much lower than those in South Korea (Korea hereafter) and China.) The Herfindahl-Hirschman Index (hereafter HHI) for the Japanese banking market in 2006 is about 1,000: HHI is calculated by the sum of the squares of each bank's market share in total bank deposits. There has been an increase in HHI from about 700 in the 1990s to about 1,000 in the 2000s. Compared to the banking markets of other countries, the Japanese banking market with this HHI value is less concentrated.

\section{Bank Merger Waves in other Countries}

In the US, lifting geographical restrictions on acquisitions and branching in the 1980s accelerated mergers and acquisitions of banks. Bank consolidation was further stimulated by the passage of the 1994 Riegle-Neal Interstate Banking and Branching Efficiency Act. This established the basis for a true nationwide banking system and accelerated bank mergers. The number of US banks fell from 14,404 in 1980 to about 12,000 in 1990 and then to about 7,100 in 2008: in all a 50 per cent decline over three decades. Although the number of banks in the US declined and their average asset and deposit sizes became large, there was no noticeable change in the concentration of the US local banking market measure of HHI. This is because much of bank consolidation in the US is typically characterized by market-extension, that is, acquisitions involving two banks in different geographical markets. Figure 1 shows that the U.S. banking industry is much less concentrated in the deposit market than those of other countries. The banking sectors in the United Kingdom, France, Japan, Sweden, Canada and Russia are all more concentrated than the US banking sector.

Over in the last twenty years, the South Korean banking system went through many changes: financial deregulation, financial crisis, and restructuring. In this process, market concentration decreased as the number of banks increased due to financial 
deregulation prior to the Asian financial crisis of 1997. After the crisis, the concentration ratio increased because of a decline in the number of banks due to bank closures and the creation of mega banks through bank consolidation.

Figure 1

\section{HHI of Domestic Deposits}

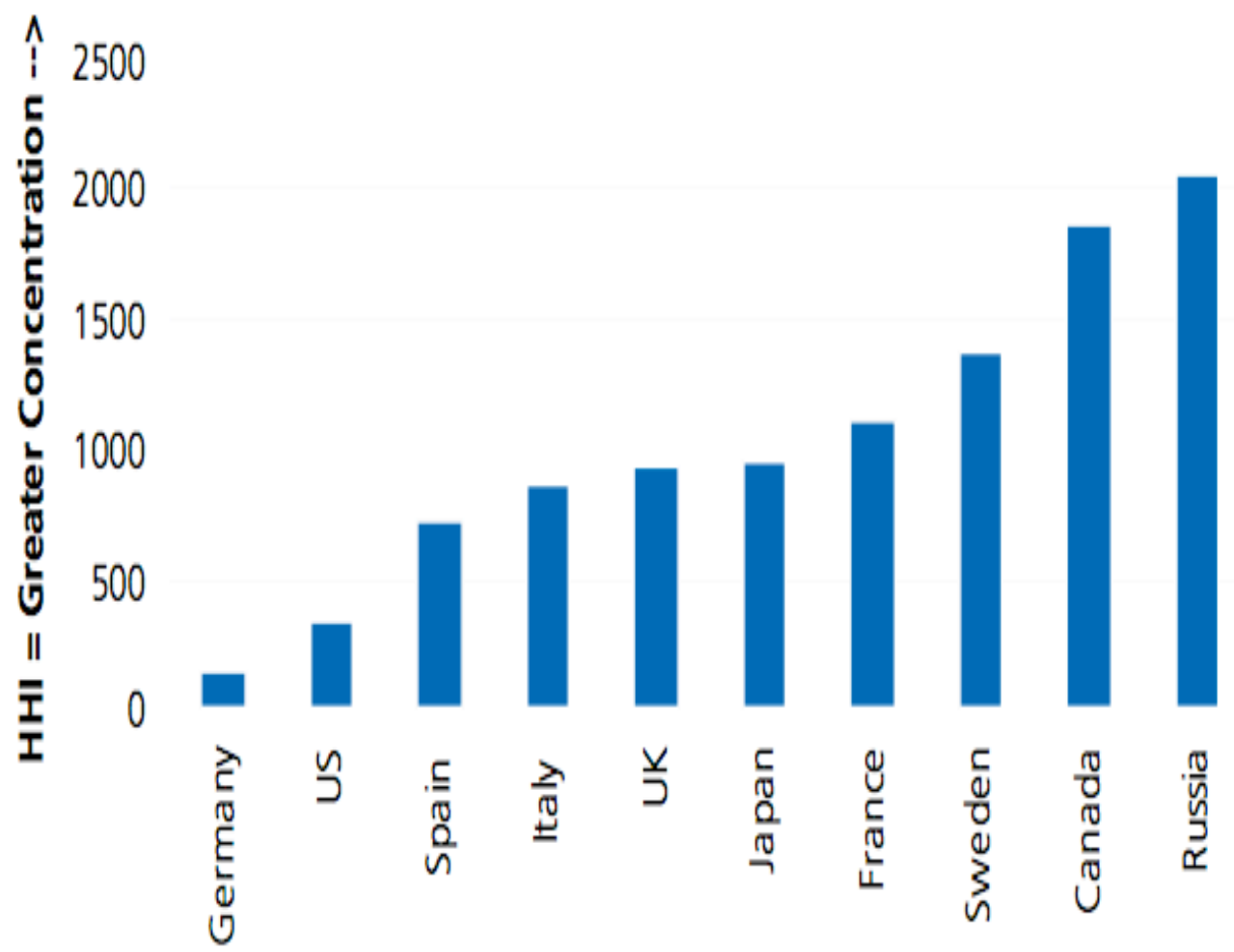

Source: Celent analysis, annual reports, central banks

This change in concentration in Korea is different from the US experience with bank consolidation. While much of bank consolidation in the US is typically characterized by market-extension mergers, which are acquisitions involving two banks in different geographical markets, bank consolidation in Korea was the result of horizontal mergers among banks with overlapping geographical markets. 
The Korean banking sector prior to the Asian financial crisis of 1997-98 can be regarded as a non-concentrated market with $\mathrm{HHI}$ less than 1,000 in total assets, total loans and total deposits according to either the Korean or the US horizontal merger guidelines. After the crisis, particularly after the second-phase restructuring in 2001, the Korean commercial banking market became a moderately concentrated market with HHI ranging between 1,300 and 1,500 according to the Korean antitrust guideline. HHI is in excess of 1,800 in some specific sub-markets such as loans to households and deposits in foreign currency (Park, 2009). Today, the three largest banks, Kookmin Bank, Woori Bank and Shinhan Banks hold about 60 per cent of total bank assets. HHI figures of Korean banks are higher than those of banks in other OECD countries of a similar population size. For example, HHI of Spanish banks was in the 700s and HHI of Italian banks was in the 600s according to the 2000 data of the European Central Bank.

On the other hand, Chinese banking system went through a different path from the US, Japan and Korean experiences. Even though there have been many bank foreclosures, takeovers and mergers in recent years, the number of new bank entering the Chinese banking market far exceeded the number of banks that disappeared. Until 1978, there was one single bank, People's Bank of China, and then along with its economic reform, the Chinese government in 1979 and 1984 authorized four state-owned commercial banks with limited competition among them. Since then the Chinese government allowed many joint equity banks and private banks in order to mobilize needed financial resources for economic development. Furthermore, it authorized several policy banks and city banks in the 1990s as a measure of financial liberalization in preparation for the entry to the World Trade Organization. All these have contributed to a continuous decrease in market concentration of the Chinese banking industry.

Contrary to the increasing trend of Korean banks' market concentration, the Chinese banking system has experienced continually decreasing market concentration from 2743 in 1994 to 1642 in 2008 (Park, 2011). This change is clearly attributable to a change in the Chinese government policy on banking, which allowed establishment of more banks and promoted competition among them. In spite of some mergers of banks occurred in recent years, the number of new banks created far exceeded the number of 
banks foreclosed and merged. Before Deng Xiao Ping’s 1978 reform, China had a mono bank, the People's Bank of China, playing both roles of central and commercial banking.

With reform, four specialized state banks were split from the People's Bank of China between 1979 and 1984, leaving the People's Bank of China solely functioning as China's central bank. Even though restrictions of these specialized banks to do business in only their designated territories were removed in 1985, competition among them was very limited until the mid 1990s. There was a boost to competition when the Chinese government authorized establishment of three policy banks.

Since 1986, 14 joint-equity banks were established, where shares were held by the government, cooperatives and private sector. During the mid 1990s, the central government allowed local governments to establish local (or city) banks. In 2008, the total number of banks exceeds 200 excluding foreign banks, and the number continuously increases year by year. Luc and Ariff (2008) show concentration reduction as a result of government policy of privatizing state banks. As the market value of the US and Western banks were reduced due to the global financial crisis of 2007-08, four Chinese banks ranked among the top 10 banks in the world. Furthermore, the top three are all Chinese banks, Industrial and Commerce Bank of China, Bank of China and Construction Bank of China.

\section{Survey of the Literature}

This section briefly reviews the theoretical models and empirical findings on bank competition, our main focus for this study. Although studies have investigate the effect of bank consolidation on competition, there is little consensus on appropriate theoretical framework, and the existing empirical findings are inconclusive. As long as there are no sunk costs and hit-and-run entry is possible, then market contestability can yield competitive pricing regardless of the number of firms (Baumol, et al., 1982). The efficient structure hypothesis advances that efficient banks obtain higher profitability and greater market share because of their efficiency, which will lead to a more concentrated market. Therefore, the association between structure and performance might be spurious 
unless efficiency is controlled in the model (Smirlock, 1985). Adverse borrower selection may result in spurious empirical Structure Conduct Performance linkages too (Shaffer, 2002).

A concern about the effect of consolidation on competition arises from the structure-conduct-performance (SCP) paradigm, which dates back to Mason (1939). The SCP model suggests that increasing market concentration leads to less competitive conduct in terms of higher prices and less output, which results in higher profits at the expense of lower consumer welfare. This paradigm is the basis of the so-called collusion hypothesis. Although there is a theoretical basis for these linkages, other equilibrium conditions can lead to different relationship between market concentration and conduct. Empirical results on the SCP paradigm are mixed. According to Gilbert (1984), many studies presented a mixed set of results in aggregate, and tended to suffer from various methodological flaws. Weiss (1989) reports that only 21 out of 47 studies support the claims of SCP model.

Two empirical methods have been developed to remedy the natural shortcomings of the SCP model by testing the conduct directly, without regard to industry structure. One method is the Bresnahan (1982, 1989) and Lau (1982) model (B-L model) which estimates the markup of price over marginal cost as a measure of market power. Thus, this method is also called the markup test. This model is based on two structural equations, an inverse demand equation and a supply equation derived from the first order condition of profit maximization. The other method is the Panzar and Rosse $(1982,1987)$ model (P-R model). This model measures the extent to which a change in a vector of input prices is reflected in gross revenue. Thus, this method is also called the revenue test. If the market is perfectly competitive, then the change will be fully reflected in revenue. Shaffer (2004) contrasts both methods in detail and discusses their advantages and disadvantages.

Numerous studies apply the P-R model empirically, beginning with Shaffer (1982) who finds monopolistic competition behavior with a sample of New York banks in 1979. Nathan and Neave (1989) reject the hypothesis of monopoly power of Canadian banks. Country-specific empirical studies include Vesala (1995) for Finland, Molyneux, 
at al. (1996) for Japan, Coccorese (1998) for Italy, Hondroyiannis (1999) for Greece, and Hempell (2002) for Germany. Molyneux, et al. (1994) and Bikker and Groeneveld (2000) find monopolistic competition in several European countries. On the other hand, De Bandt and Davis (2000) find monopolistic competition for large banks and monopoly for small banks in Germany and France. Bikker and Haaf (2002) find that the banking industries in 23 OECD countries for the period 1998-1999 are generally characterized by monopolistic competition with the exception of Australia and Greece. Gelos and Roldos (2002) compare eight European and Latin American countries and find that the bank consolidation process in its early stage has not lowered competition.

For Japanese bank competition, there were several studies based on the stochastic cost frontier approach. The P-R model was first applied by Molyneux et al. (1996) to data of Japanese commercial banks. They find that the Japanese banking market was under monopoly or conjectural variations short-run oligopoly in 1986 while improving the level of monopolistic competition in 1988. Uchida and Tsutsui (2005), using long-term panel data from 1974-2000, find that the market competition had improved, especially in the 1970s and in the first half of the 1980s, but it had deteriorated after 1997. They also find that competition among city banks in metropolitan areas was stronger than that among regional banks in rural areas. Lee and Nagano (2008) report that market concentration that was brought about by bank mergers has not necessarily resulted in low competition.

There are a few studies on Korean banking competition. Two different results are reported for Korea. Lee and Kim (1995) and Lee (2003), applying the P-R model, find that banking competition in Korea improved along with financial deregulation. Kim (2003), which measures competition using the B-L model based on aggregate monthly data from 1996 to 2002, finds that the pricing behavior of Korean banks during this period is consistent with perfect competition and that they behave more competitively even after the increase in concentration ratio. On the other hand, using the P-R model, Kim et al. (2004) and Lee and Lee (2005) find that banking competitiveness weakened significantly along with an increase in market concentration after the 1997-8 Korean financial crisis. Recently, Park (2009) resolved the conflicting results by dividing the sample period of 1992-2004 into three separate periods, and report Korean banking 
market has been monopolistically competitive during the pre-crisis period and post-crisis period with temporary deviation to the level of perfect competition during the crisis period.

Studies on bank competition in China are scanty and are mostly descriptive rather than analytical, simply reporting the trend of bank concentration without further investigative analysis. Park (2011) shows that even though the competitive conditions of the Chinese banking market have definitely improved over time, the Chinese banking market still has an oligopolistic market structure.

\section{Panzar-Rosse H-Model}

The P-R model is generally regarded to be robust to the extent that market and bank level data are available, even though Bikker at al. (2006) stated that inclusion of a scale variable in the model may cause overestimation of the level of competition. Furthermore, Shaffer (1982) showed that the H-statistic of the P-R model is inversely related to the index of monopoly power $[\mathrm{q} / \mathrm{Q}(\partial \mathrm{Q} / \partial \mathrm{q})]$ of the B-L model under certain conditions, where $\mathrm{q}$ is a bank' s output and Q is output by all banks. So, we use the P-R model in this study to assess the competitive nature of the Japanese banking industry.

Let a bank's revenue function be $R_{i}=R_{i}\left(x_{i}, y_{1 i}\right)$, where $x_{i}=$ a vector of output of bank $\mathrm{i}$ and $\mathrm{y}_{1 \mathrm{i}}=\mathrm{a}$ vector of exogenous variables which affect the revenue function of bank i. A bank's cost function is assumed to be $C_{i}=C_{i}\left(x_{i}, p_{i}, y_{2 i}\right)$, where $p_{i}$ is a vector of $\mathrm{k}$ factor input prices of bank $\mathrm{i}$ and $\mathrm{y}_{2 \mathrm{i}}=\mathrm{a}$ vector of exogenous variables which affect the cost function of bank $\mathrm{i}$. The vectors $\mathrm{y}_{1 \mathrm{i}}$ and $\mathrm{y}_{2 \mathrm{i}}$ may include common variables.

Profit maximization by the bank requires that marginal revenue equal marginal cost as

$$
\mathrm{R}_{\mathrm{i}}^{\prime}\left(\mathrm{x}_{\mathrm{i}}, \mathrm{y}_{1 \mathrm{i}}\right)=\mathrm{C}_{\mathrm{i}}^{\prime}\left(\mathrm{x}_{\mathrm{i}}, \mathrm{w}_{\mathrm{i}}, \mathrm{y}_{2 \mathrm{i}}\right)
$$

Market power can be measured by the degree to which a change in factor input prices affects the change in the revenue function at equilibrium. Therefore, Panzar and Rosse 
(1987) calculated the sum of the elasticities of the revenue with respect to factor input prices from the reduced-form revenue equation and define it as the H-statistics.

$$
\mathrm{H}=\Sigma\left(\partial \mathrm{R}_{\mathrm{i}} / \partial \mathrm{p}_{\mathrm{ki}}\right)\left(\mathrm{p}_{\mathrm{ki}} / \mathrm{R}_{\mathrm{i}}\right)
$$

where $R_{i}$ is revenue of bank $i$ and $p_{k i}$ is $k^{\text {th }}$ input price of bank $i$.

Panzar and Rosse (1987) showed from the profit maximization condition that the $\mathrm{H}$-statistic is equal to unity $(\mathrm{H}=1)$ in a perfectly competitive market, and less than or equal to zero $(\mathrm{H} \leq 0)$ under monopoly. If the market is perfectly competitive, then the change will be fully reflected in revenue. Although the Panzar-Rosse article also shows that $0<\mathrm{H}<1$ could be consistent with oligopolistic behavior, it is common to regard $0<\mathrm{H}<1$ as the condition of Camberlinian monopolistic competition. This interpretation is valid under the assumption that the observations are in the long-run equilibrium (Nathan \& Neave, 1989).

For estimation purpose, following Park (2009), the reduced-form revenue equation of a bank can be specified as follows.

$$
\ln \left(\mathrm{R}_{\mathrm{it}}\right)=\alpha+\beta_{1} \ln \left(\mathrm{w}_{\mathrm{it}}\right)+\beta_{2} \ln \left(\mathrm{c}_{\mathrm{it}}\right)+\beta_{3} \ln \left(\mathrm{f}_{\mathrm{it}}\right)+\Sigma \gamma_{1 \mathrm{~h}} \mathrm{~S}_{\mathrm{h}}+\Sigma \gamma_{2 \mathrm{k}} \mathrm{V}_{\mathrm{k}}+\varepsilon_{\text {it }}
$$

where $\mathrm{R}_{\mathrm{it}}$ is bank i's revenue at time $t, \mathrm{w}_{\mathrm{it}}$ is bank i's factor input price of labor at time $t, \mathrm{c}$ is bank i's factor input price of capital at time $t$, $f$ is bank i's factor input price of funds at time $t, S_{h}$ is a vector of scale variables, and $V_{k}$ is a vector of control variables other than scale variables that affect the bank's revenue function. The H-statistic is the sum of $\beta_{1}, \beta_{2}$ and $\beta_{3}$. In order to eliminate manual calculation of $\beta_{1}+\beta_{2}+\beta_{3}$ and its standard error, equation (3) can be rearranged as follows.

$$
\begin{aligned}
\ln \left(\mathrm{R}_{\mathrm{it}}\right)= & \alpha+\beta_{1}\left[\ln \left(\mathrm{W}_{\mathrm{it}}\right)-\ln \left(\mathrm{f}_{\mathrm{it}}\right)\right]+\beta_{2}\left[\ln \left(\mathrm{c}_{\mathrm{it}}\right)-\ln \left(\mathrm{f}_{\mathrm{it}}\right)\right] \\
& +\left(\beta_{1}+\beta_{2}+\beta_{3)} \ln \left(\mathrm{f}_{\mathrm{it}}\right)+\Sigma \gamma_{1 \mathrm{~h}} \mathrm{~S}_{\mathrm{h}}+\Sigma \gamma_{2 \mathrm{k}} \mathrm{V}_{\mathrm{k}}+\varepsilon_{\mathrm{it}}\right.
\end{aligned}
$$

The H-statistics is estimated by the coefficient of $\ln \left(\mathrm{f}_{\mathrm{it}}\right)$ which is $\beta_{1}+\beta_{2}+\beta_{3}$, and its statistical significance can be tested by the standard error. 
Competitive conditions are usually reflected in net interest margin. It is generally expected that the more market is dominated by a few mega banks and the more concentrated the banking market becomes, the higher is the net interest margin. So, to further examine the effect of bank mergers on bank competition, the following equation is estimated.

$$
\mathrm{M}_{\mathrm{it}}=\alpha+\beta_{\mathrm{k}} \Sigma \mathrm{X}_{\mathrm{k}, \mathrm{it}}+\gamma_{\mathrm{k}} \Sigma \mathrm{Y}_{\mathrm{k}, \mathrm{it}}+\delta_{\mathrm{k}} \Sigma \mathrm{Z}_{\mathrm{k}, \mathrm{t}}+\varepsilon_{\mathrm{it}}
$$

where $M_{i t}=$ the average net interest margin of bank $\mathrm{i}$ at time $t, X_{k, i t}=$ bank specific variables of bank $\mathrm{i}$ at time $\mathrm{t}$, such as equity ratio, the share of non performing loans and number of branches, $\mathrm{Y}_{\mathrm{k} \text {, it }}=$ market power variables of bank $\mathrm{i}$ at time $\mathrm{t}$, such as the market share and HHI. $\mathrm{Z}_{\mathrm{k}, \mathrm{t}}=$ macroeconomic variables such as economic growth rate, inflation rate and a dummy variable for the crisis period.

\section{Empirical Results: Did Competition Reduce?}

The data used for this analysis are from the Nikkei Financial Quest Database. The Japanese banking industry has had three distinctive time periods. The first period is from 1983 to 1988 when banks experienced an unprecedented boom along with the bubbles in the real estate market and the stock market until the bubbles burst. The second period is from 1989 to 1998 when banks experienced hard time with increasing non-performing loans, profit losses eventually leading to bankruptcy of major banks and a bank crisis. The third period is form 1999 to 2006 when the banking sector experienced merger waves and improved its performance thanks to the government's several financial reforms to promote competition.

Even though there are several different types of commercial banks in Japan as explained in section 2, city banks and regional banks (both tier 1 and tier 2) account for over 80 per cent of total bank assets and total bank loans. So, they are selected as the sample for this study. As some banks entered while others exited during the sample period, unbalanced panel data are used for analysis. The Chow breakpoint test is used to see whether we can treat the whole period as a homogenous period or not, that is, whether 
there is no significant difference in the estimated equations between the sub-periods. The test of the null hypothesis of no structural change is rejected. The fixed effect model is used to reflect bank-specific characteristics and to control heterogeneity among banks.

The revenue of a bank $\left(\mathrm{R}_{\mathrm{it}}\right)$ is typically measured by interest revenue or its ratio to total assets, presuming that the main function of banks is financial intermediation. However, with weakening of financial intermediation in recent years and diversification of bank assets, total revenue or its ratio to total assets is used in some studies. So, both interest revenue and total revenue are used in this study. For factor input prices, the following formulas are used.

$$
\begin{aligned}
& \mathrm{w}_{\mathrm{it}}=\text { personnel expenses/the number of employees, } \\
& \mathrm{c}_{\mathrm{it}}=\text { depreciation allowance and other maintenance costs/total fixed assets, } \\
& \mathrm{f}_{\mathrm{it}}=\text { interest expenses/the sum of total deposits and borrowings. }
\end{aligned}
$$

Recently there has been an increase in part-time and contractual workers as banks try to reduce costs. However, only full-time workers and their expenses are considered here.

Two scale variables are included in the model. Total assets (ASSET) are included to see the size effect while the number of branches (BRANCH) is included to account for the effect of bank networks. Several bank specific variables are included as control variables. The ratio of risk-adjusted equity to total assets (EQUITY) is used as a control variable for credit market and operational risk while the ratio of non-performing loans to total loans (NPL) is included to control for the risk effect. Even though financial intermediation is the core business of banks, the Japanese banking sector experienced weakening of its financial intermediation function over time, which is a common phenomenon all over the world. To reflect the effect of changing financial intermediation or diversification, the ratio of non-interest revenue to total revenue (NONINT) is included in the estimation equation.

The estimated results of Equation (4), using both the interest revenue and the total revenue as the dependent variable, for city banks in Japan are reported in Tables 1 . The two scale variables, Asset and Branch, are highly correlated. Furthermore, Bikker et al. 
(2006) stated that inclusion of a scale explanatory variable such as ASSET in the P-R model may cause overestimation of the level of competition and may distort the test results. So, the variable ASSET is deleted from the estimation equation, and only the variable BRANCH, representing bank network, is used.

Table 1: Estimation Results of Equation (4), City Banks

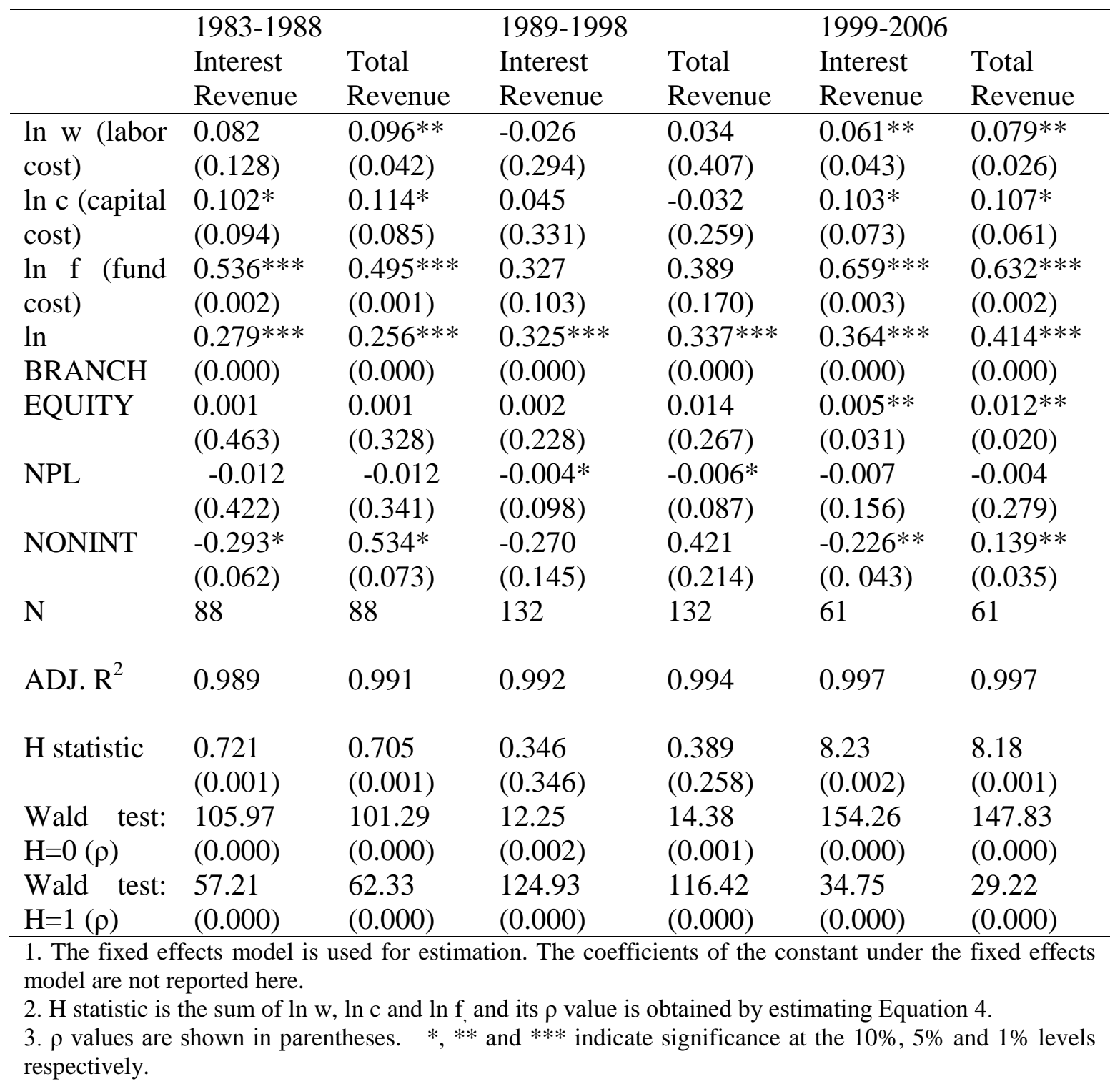

With the interest revenue as the dependent variable, the H-statistic dropped significantly from 0.721 for the period of 1983-1988 to 0.346 for the period of 19891999, but increased to 0.823 for the period of 2000-2006. The Wald test rejects the 
hypothesis of monopolistic market structure $(\mathrm{H}=0)$ and the hypothesis of perfectly competitive market structure $(\mathrm{H}=1)$ at the $1 \%$ level for all three periods. A similar pattern is found in the model when the total revenue is used as the dependent variable. The $\mathrm{H}$ statistic changed from 0.705 for the period of 1983-1988 to 0.389 for the period of 19891999, but increased to 0.818 for the period of 2000-06. The Wald tests render the same conclusion about the market structure of the Japanese commercial banking market. The estimation results of the $\mathrm{H}$-statistic with two different dependent variables, the interest revenue and the total revenue, are robust.

Among the three factor input prices, the unit funding cost (ln f) is the most influential variable affecting a change in revenue in terms of the magnitude of the coefficient and it is also statistically most significant. However, its effect on revenue diminished during period 2. All three factor input prices usually exhibit positive coefficients. But during period 2, the unit labor cost (ln w) as well as the unit capital cost (ln c) are not statistically significant and sometimes they exhibit negative coefficient. The positive sign and significant coefficient of BRANCH indicates the presence of the network effect. EQUITY became significant after the government carries out the financial reform and applied more strict accounting standards. According to the signal theory, banks that are expected to have better performance in terms of profitability will credibly transmit this information through a higher equity ratio according to the signal theory. Significance of the coefficient of EQUITY in period 3 vindicates the signal theory.

NPL had a significant negative effect on revenue during period 2 while not being a major determinant during the earlier boom or during the recovery period. NONINT has a significant negative effect on interest revenue while having a significant positive effect on total revenue as evidence by the weakening of the financial intermediary function of banks. This coincides with the consolidation of banks and creation of mega banks. Mega banks have expanded their business into non-loan-related activities such as security investments. It can be inferred that the Japanese city banks in major metropolitan areas have been monopolistically competitive with the exception for period 2 when competition decreased sharply with economic stagnation and financial crisis. 
Table 2 reports the estimated results of equation (4), using both the interest revenue and the total revenue as the dependent variable, for regional banks in Japan. There are no noticeable changes in the H-statistic across three different periods, whether the interest rate or the total revenue are used as the dependent variable. The values of the H-statistic are lower than those for city banks in period 1 and period 3. Similar results are obtained in regard to three factor input prices: significant and positive effect of the unit fund cost compared to the unit labor cost and the unit capital cost. The network effect

Table 2: Estimation Results of Equation (4), Regional Banks

\begin{tabular}{|c|c|c|c|c|c|c|}
\hline & \multicolumn{2}{|c|}{\begin{tabular}{|l|}
$1983-1988$ \\
\end{tabular}} & \multicolumn{2}{|c|}{ 1989-1998 } & \multicolumn{2}{|c|}{ 1999-2006 } \\
\hline & $\begin{array}{l}\text { Interest } \\
\text { Revenue }\end{array}$ & $\begin{array}{l}\text { Total } \\
\text { Revenue }\end{array}$ & $\begin{array}{l}\text { Interest } \\
\text { Revenue } \\
\end{array}$ & $\begin{array}{l}\text { Total } \\
\text { Revenue } \\
\end{array}$ & $\begin{array}{l}\text { Interest } \\
\text { Revenue }\end{array}$ & $\begin{array}{l}\text { Total } \\
\text { Revenue }\end{array}$ \\
\hline $\begin{array}{l}\text { ln } w \text { (labor } \\
\text { cost) }\end{array}$ & $\begin{array}{l}0.151 * * \\
(0.042)\end{array}$ & $\begin{array}{l}0.106 * * \\
(0.031)\end{array}$ & $\begin{array}{l}0.131 * \\
(0.093)\end{array}$ & $\begin{array}{l}0.115 \\
(0.116)\end{array}$ & $\begin{array}{l}0.143 * * \\
(0.013)\end{array}$ & $\begin{array}{l}0.141 * \\
(0.066)\end{array}$ \\
\hline $\begin{array}{l}\text { ln c (capital } \\
\text { cost) }\end{array}$ & $\begin{array}{l}0.056 \\
(0.129)\end{array}$ & $\begin{array}{l}0.112^{* *} \\
(0.025)\end{array}$ & $\begin{array}{l}0.042 \\
(0.244)\end{array}$ & $\begin{array}{l}-0.026 \\
(0.321)\end{array}$ & $\begin{array}{l}0.012 \\
(0.103)\end{array}$ & $\begin{array}{l}0.053 * \\
(0.066)\end{array}$ \\
\hline $\begin{array}{l}\ln f \text { (fund } \\
\text { cost) }\end{array}$ & $\begin{array}{l}0.314^{* * *} \\
(0.000)\end{array}$ & $\begin{array}{l}0.319 * * * \\
(0.000)\end{array}$ & $\begin{array}{l}0.225 * \\
(0.062)\end{array}$ & $\begin{array}{l}0.323 * \\
(0.073)\end{array}$ & $\begin{array}{l}0.341 * * * \\
(0.003)\end{array}$ & $\begin{array}{l}0.264 * * * \\
(0.004)\end{array}$ \\
\hline $\begin{array}{l}\ln \\
\text { BRANCH }\end{array}$ & $\begin{array}{l}0.279 * * * \\
(0.002)\end{array}$ & $\begin{array}{l}0.256 * * * \\
(0.001)\end{array}$ & $\begin{array}{l}0.273 * * * \\
(0.003)\end{array}$ & $\begin{array}{l}0.213^{* * *} \\
(0.001)\end{array}$ & $\begin{array}{l}0.304 * * * \\
(0.004)\end{array}$ & $\begin{array}{l}0.272 * * \\
(0.012)\end{array}$ \\
\hline EQUITY & $\begin{array}{l}0.002 * \\
(0.091)\end{array}$ & $\begin{array}{l}0.001 \\
(0.132)\end{array}$ & $\begin{array}{l}0.006 * \\
(0.083)\end{array}$ & $\begin{array}{l}0.004 \\
(0.117)\end{array}$ & $\begin{array}{l}0.011 * \\
(0.094)\end{array}$ & $\begin{array}{l}0.007^{*} \\
(0.080)\end{array}$ \\
\hline NPL & $\begin{array}{l}-0.026 * \\
(0.082)\end{array}$ & $\begin{array}{l}0.015^{* *} \\
(0.034)\end{array}$ & $\begin{array}{l}-0.091^{* *} \\
(0.041)\end{array}$ & $\begin{array}{l}-0.044^{*} \\
(0.069)\end{array}$ & $\begin{array}{l}-0.019 \\
(0.104)\end{array}$ & $\begin{array}{l}-0.014^{*} \\
(0.089)\end{array}$ \\
\hline NONINT & $\begin{array}{l}-0.191 \\
(0.126)\end{array}$ & $\begin{array}{l}0.074 \\
(0.135)\end{array}$ & $\begin{array}{l}-0.170 \\
(0.198)\end{array}$ & $\begin{array}{l}0.051 \\
(0.143)\end{array}$ & $\begin{array}{l}-0.124^{*} \\
(0.093)\end{array}$ & $\begin{array}{l}0.111 \\
(0.142)\end{array}$ \\
\hline $\mathrm{N}$ & \begin{tabular}{|l|}
792 \\
\end{tabular} & 792 & 1291 & 1291 & 872 & 872 \\
\hline ADJ. $\mathrm{R}^{2}$ & 0.994 & 0.995 & 0.982 & 0.975 & 0.998 & 0.996 \\
\hline H statistic & $\begin{array}{l}0.521 \\
(0.001)\end{array}$ & $\begin{array}{l}0.537 \\
(0.001)\end{array}$ & $\begin{array}{l}0.398 \\
(0.004)\end{array}$ & $\begin{array}{l}0.412 \\
(0.005)\end{array}$ & $\begin{array}{l}0.496 \\
(0.001)\end{array}$ & $\begin{array}{l}0.454 \\
(0.002)\end{array}$ \\
\hline $\begin{array}{l}\text { Wald test: } \\
\mathrm{H}=0(\rho)\end{array}$ & $\begin{array}{l}178.34 \\
(0.000)\end{array}$ & $\begin{array}{l}181.81 \\
(0.000)\end{array}$ & $\begin{array}{l}35.29 \\
(0.000)\end{array}$ & $\begin{array}{l}37.48 \\
(0.000)\end{array}$ & $\begin{array}{l}151.67 \\
(0.000)\end{array}$ & $\begin{array}{l}127.83 \\
(0.000)\end{array}$ \\
\hline $\begin{array}{l}\text { Wald test: } \\
\mathrm{H}=1(\rho)\end{array}$ & $\begin{array}{l}167.97 \\
(0.000)\end{array}$ & $\begin{array}{l}156.42 \\
(0.000)\end{array}$ & $\begin{array}{l}114.39 \\
(0.000)\end{array}$ & $\begin{array}{l}101.73 \\
(0.000)\end{array}$ & $\begin{array}{l}163.34 \\
(0.000)\end{array}$ & $\begin{array}{l}140.16 \\
(0.000)\end{array}$ \\
\hline
\end{tabular}

1. The fixed effects model is used for estimation. The coefficients of the constant under the fixed effects model are not reported here.

2. $H$ statistic is the sum of $\ln w, \ln c$ and $\ln f$, and its $\rho$ value is obtained by estimating Equation 4 .

3. $\rho$ values are shown in parentheses. ${ }^{*},{ }^{* *}$ and $* * *$ indicate significance at the $10 \%, 5 \%$ and $1 \%$ levels respectively. 
which is present for city banks is also confirmed for regional banks by BRANCH's positive and significant coefficient. EQUITY has a positive effect on revenue while NPL has a negative effect on revenue as expected. NONINT has a negative effect on interest revenue while having a positive effect on total revenue. Contrast to significant effect of NONINT for city banks, it is not a significant variable for regional banks, implying that regional banks are less diversified than city banks.

The estimated results of Equation (5) for both city banks and regional banks, covering the entire sample period, are presented in Table 3.

Table 3: Estimation Results of Equation (5), Dependent Variable: Net Interest Margin

\begin{tabular}{|c|c|c|c|}
\hline Category & Variable & City banks & Regional banks \\
\hline \multirow[t]{4}{*}{$\begin{array}{ll}\text { Bank } & \text { Specific } \\
\text { Variables } & \end{array}$} & EQUITY & $\begin{array}{l}0.073 \\
(0.129)\end{array}$ & $\begin{array}{c}0.022^{*} \\
(0.045)\end{array}$ \\
\hline & NPL & $\begin{array}{l}-0.022^{* *} \\
(0.000)\end{array}$ & $\begin{array}{l}-0.016^{* *} \\
(0.000)\end{array}$ \\
\hline & BRANCH & $\begin{array}{l}0.182^{*} \\
(0.031)\end{array}$ & $\begin{array}{l}0.093 \\
(0.067)\end{array}$ \\
\hline & NONINT & $\begin{array}{l}-0.011^{* *} \\
(0.003)\end{array}$ & $\begin{array}{l}-0.027^{* *} \\
(0.000)\end{array}$ \\
\hline \multirow[t]{2}{*}{$\begin{array}{l}\text { Market Power } \\
\text { Variables }\end{array}$} & $\begin{array}{l}\text { Market Share } \\
\text { (assets) }\end{array}$ & $\begin{array}{l}-0.012 \\
(0.247)\end{array}$ & $\begin{array}{l}-0.144^{* *} \\
(0.000)\end{array}$ \\
\hline & HHI (assets) & $\begin{array}{l}0.925 \\
(0.110)\end{array}$ & $\begin{array}{l}-1.347^{*} \\
(0.046)\end{array}$ \\
\hline \multirow[t]{3}{*}{$\begin{array}{l}\text { Macro } \\
\text { Variables }\end{array}$} & $\begin{array}{ll}\text { GDP } & \text { Growth } \\
\text { Rate } & \\
\end{array}$ & $\begin{array}{l}-0.012^{*} \\
(0.042)\end{array}$ & $\begin{array}{l}-0.003 \\
(0.241)\end{array}$ \\
\hline & Inflation Rate & $\begin{array}{l}0.013 \\
(0.271)\end{array}$ & $\begin{array}{l}0.022 \\
(0.473)\end{array}$ \\
\hline & $\begin{array}{l}\text { Dummy } \\
\text { (CRISIS) }\end{array}$ & $\begin{array}{l}-0.136^{* *} \\
(0.002)\end{array}$ & $\begin{array}{l}-0.189^{* *} \\
(0.001)\end{array}$ \\
\hline \multicolumn{2}{|l|}{$\mathrm{N}$} & 281 & 2955 \\
\hline \multicolumn{2}{|l|}{ Adj. $R^{2}$} & 0.951 & 0.978 \\
\hline
\end{tabular}

1. Estimation results of fixed effects model. The coefficients of the constant under the fixed effects model are not reported here.

2. $\rho$ values are shown in parentheses. * and $* *$ indicate significance at the $5 \%$ and $1 \%$ levels respectively. 
The average interest margin for regional banks is usually higher than that for city banks because interest rates for small and medium enterprises typically serviced by regional banks include larger costs and risk premiums than interest rates for corporate loans typically serviced by national banks. Instead of dividing the sample into three separate periods, the equation is estimated for the entire sample period, using a dummy variable, CRISIS as a breakpoint.

EQUITY has a positive effect on net interest margin and this result is consistent with the signaling theory, which suggests that a higher equity ratio increases confidence among bank customers, leading to higher interest spread. The coefficient of EQUITY is significant for regional banks, but not for city banks. NPL has a significant negative effect for both city banks and regional banks as expected. Loans are the major incomeearning asset of banks and higher percentage of non-performing loans negatively affects the interest spread. BRANCH shows a positive influence on interest spread through bank network effect, particularly for city banks. The negatively significant relationship between NONINT and net interest margin indicates that Japanese banks, regardless of city banks or regional banks, have diversification effect. The banks with higher level of diversification exhibit lower net interest margin.

Two market power variables are used: market share of each bank and HHI indicating the overall degree of market concentration. The most troublesome interpretation of the estimated results is related to these two market power variables. Contrary to what a typical theory of industrial organization would predict, the market share has a negative effect on net interest margin while HHI renders a mixed result, positive for city banks, but negative for regional banks. The GDP growth rate and inflation rate have positive, though not significant in some cases, effects on the average interest margin. The dummy variable, CRISIS, is significant in explaining the interest spread. An increase in individual bank's market share and an increase in overall market concentration are not linked to higher net interest margin in Japan. 


\section{Comparison to the Korean and Chinese Experiences}

Even though the Korean commercial banking market has become increasingly concentrated in the process of restructuring since the crisis, Park (2009) shows that bank competition in Korea has not been negatively affected by bank consolidation. The Korean banking system may have remained competitive despite its consolidation due to the entry of foreign banks and increased foreign ownership of domestic banks. Actually the competition condition test shows competition in the Korean banking sector increased to the level of perfect competition during the Korean financial crisis period, which is quite the opposite of what happened during Japan's financial trouble time. In Korea, the net interest margin is positively correlated with the market share as expected while in Japan they are negatively correlated.

In spite of these differences, Japanese and Korean banking industries have a common trend in their merger activities and market concentration. Both countries experienced an increase in bank mergers, creation of a few mega banks and an increase in market concentration ratio measured by HHI. The degree of market concentration is much higher in Korea than in Japan (1,500 vs. 1000 in HHI). Both banking markets have a market structure of monopolistic competition. Comparing the values of the H-statistic obtained by Lee and Nagano (2008), Park (2009) and this study, it may be stated that the city banks in Japan tend to be more competitive than its Korean counterparts while the Korean regional banks are more competitive than its Japanese counterpart.

China has a quite different picture from Japan and Korea. The bank merger wave began in the US and spread to Europe, Japan and Korea. However, this wave has not yet hit the Chinese banking market because of its restricted financial openness and government regulation on banking. Bank mergers in China were typically governmentinitiated rather than market-initiated. While there has been an increase in market concentration in Japan and Korea along with an increase in merger activities among banks, China moved from a more concentrated market to a less concentrated market.

For China, the competitive conditions of the Chinese banking industry have definitely improved over time. The Chinese banking system progressed from one bank 
system to 4 state banks system in the 1980s to more than 20 banks including joint-equity commercial banks in the 1990s to more than 200 banks at the present time. In spite of a drastic decrease in market concentration of the Chinese banking industry, its competition conditions are far from a competitive market, as evidenced by the H-statistic. The sheer number of banks does not guarantee a competitive market. Lowering entry barriers for private banks and foreign banks would further facilitate competition. Institutional changes and lifting government regulations on banking are also necessary to speed up competitive behaviors in the market.

\section{Conclusion on Public Policy}

Worldwide financial liberalization and financial globalization is causing fierce competition among banks all over the world. This necessitates bank mergers and consolidation within a country and across countries to achieve scale efficiency, to take advantage of diversification or just to survive. The collusion hypothesis suggests that mergers might be initiated by banks in order to extract consumer surplus, and the result would be higher prices to consumers and socially inefficient allocation of resources.

In this case enforcement of antitrust policy may be justified. However, this study does not find evidences to support the collusion hypothesis in Japan. Recent mergers in the Japanese banking sector do not seem to harm the competition level in the banking market, contrary to a growing concern over creation of mega banks. This paper concludes that the bank mergers that took place so far in Japan have not led to a higher level of market power except over a short period of financial crisis that started the bubble bursting. This conclusion is also confirmed from the empirical evidence that an increase in individual bank's market share and an increase in overall market concentration have not materialized in higher net interest margin in Japan. Further study is encouraged to test if other models produce congruent results for Japan.

Author Information: Kang H. Park is a teaching staff at the Southeast Missouri State University, United States. He may be contacted via E-mail: khpark@semo.edu. 


\section{References}

Baumol, W. J., Panzar, J.C., \& Willig, R. D. (1982). Contestable Markets and the Theory of Industry Structure. San Diego: Harcourt Brace Jovanovich.

Bikker, J. A., \& Groeneveld, J. M. (2000). Competition and concentration in the EU banking industry. Kredit und Kapital, 33(1), 62-98.

Bikker, J. A. \& Haaf, K. (2002). Competition, concentration and their relationships: an empirical analysis of the banking industry. Journal of Banking and Finance, 26, 2191-2214.

Bikker, J.A., Spierdijk, L., \& Finnie, P. (2006). Misspecification in the Panzar-Rosse mdel: assessing competition in the banking industry, DNB Working Paper 114 (www.dnb.nl).

Bresnahan, T. F. (1982). The oligopoly solution concept is identified. Economics Letters, $10,87-92$.

Bresnahan, T. F. (1989). Empirical studies of industries with market power. In R. Schmalensee, \& R. D. Willig (Eds.), Handbook of Industrial Organization (Vol. II, Chapter 17, pp. 1011-1057). New York: North-Holland.

Luc, Can and Ariff, M., (2008) Cost and Profit Efficiency of banks: A Non-parametric Analysis, China Economic Review, Vol 19: 260-278.

Casu, B., Girardone, C. and Molyneux, P. (2006), Introduction to Banking. Harlow: FT Prentice Hall.

Coccorese, P. (1998). Assessing the competitive conditions in the Italian banking system: some empirical evidence. BNL Quarterly Review, 205, 171-191.

De Bandt, O., \& Davis, E. P. (2000). Competition, contestability and market structure in European banking sectors on the eve of EMU. Journal of Banking and Finance, 24(6), 1045-1066.

Gelos, R. G., \& Roldos, J. (2002). Consolidation and Market Structure in Emerging Market Banking Systems. IMF Working Paper, No. 02/186.

Gilbert, R. A. (1984). Bank market structure and competition: a survey. Journal of Money, Credit, and Banking 16 (4 Part 2), 617-644.

Hempell, H. S. (2002). Testing for Competition among German Banks. Discussion Paper, Economic Research Center for the Deutsche Bundesbank.

Hondroyiannis, G., Lolos, S., \& Papapetrou, E. (1999). Assessing competitive conditions in the Greek banking system, Journal of International Financial Markets, Institutions and Money, 9, 377-391.

Hosono, K, Sakai, K. \& Tsuru, K. (2007). Consolidation of Banks in Japan: Causes and Conequences. RIETI discussion Paper Series 07-E-059.

Japanese Bankers Association. (2006). The Banking System in Japan. Tokyo: Zenginkyo.

Kim, B., Chun, S. \& Owe,O. (2004). An effect of financial adjustment on the degree of competition in the Korean banking industry. Industrial Economic Analysis, 17, 55-80 (in Korean).

Kim, H. (2003). Assessing concentration and competition in the Korean banking industry (in Korean). KDI Policy Studies, 25, 57-98.

Lau, L. (1982). On identifying the degree of competitiveness from industry price and output data. Economics Letters, 10, 93-99.

Lee, B. (2003). The effect of financial restructuring on the degree of competition of the 
Korean banking sector. Economic Analysis, 9, 75-113 (in Korean).

Lee, Y. and Kim, S. (1995). An effect of new entry to banking competition. Economic Analysis, 43, 165-82 (in Korean).

Lee, M. \& Nagano, M. (2008). Market competition before and after bank merger wave: a comparative study of Korea and Japan. Pacific Economic Review, 13, 604-619.

Lee S. \& Lee, J. (2005). Bank consolidation and bank competition: an empirical analysis of the Korean banking industry (in Korean). Economic Papers, 8, 102-144.

Liu, H \& Wilson, J. (2009). The Profitability of Banks in Japan: The Road to Recovery? Working Paper Series 06/09.

Mason, E. S. (1939). Price and production policies of large-scale enterprise. American Economic Review, 29, 61-74.

Molyneux, P., Lloyd-Williams, D. M., \& Thornton, J. (1994). Competitive conditions in European banking, Journal of Banking and Finance, 18, 445-459.

Molyneux, P., Thornton, J., \& Lloyd-Williams, D. M. (1996). Competition and market contestability in Japanese commercial banking. Journal of Economics and Business, 48(1), 33-45.

Nathan, A., \& Neave, E. H. (1989). Competition and contestability in Canada's financial system: empirical results. Canadian Journal of Economics, 22(3), 576-594.

Park, K. (2009). Has Bank Consolidation in Korea Lessened Competition? Quarterly Review of Economics and Finance, 49, 2009, 651-667.

Park, K. (2011). Bank Competition and Concentration: A Comparative Study of South Korea and China. Working Paper, Southeast Missouri State University.

Panzar, J. C., \& Rosse, J. N. (1982). Structure, Conduct and Comparative Statics. Bell Laboratories Economic Discussion Paper.

Panzar, J. C., \& Rosse, J. N. (1987). Testing for 'monopoly' equilibrium. Journal of Industrial Economics, 35, 443-456.

Shaffer, S. (1982). A nonstructural test for competition in financial markets. Proceedings of a Conference on Bank Structure and Competition. Federal Reserve Bank of Chicago, 225-243.

Shaffer, S. (2002). Competitive bank pricing and adverse selection, with implications for testing the SCP hypothesis. Quarterly Review of Economics and Finance, 42(3), 633-647.

Shaffer, S. (2004). Patterns of competition in banking. Journal of Economics \& Business, 56, 287-313.

Smirlock, M. (1985). Evidence on the (non) relationship between concentration and profitability in banking. Journal of Money, Credit, and Banking, 17, 69-83.

Uchida, H. \& Tsutsui, Y. (2005). Has competition in the Japanese banking sector improved? Journal of Banking and Finance 29, 419-439.

Uchida, H. and Udell, G. (2009). Banking in Japan. in Berger, A.N., Molyneux, P. and Wilson, J.O.S. (eds.) Oxford Handbook of Banking. Oxford: Oxford University Press.

Vesala, J. (1995). Testing for Competition in Banking Behavioral Evidence from Finland. Helsinki: Bank of Finland.

Weiss, L. W. (1989). A review of concentration-price studies in banking. In L. W. Weiss (Ed.), Concentration and Price. Cambridge, MA: MIT Press, 219-254. 